\title{
Psychological Violence and Associated Factors Among Housemaid's in Northwest Ethiopia.
}

Kefyalew Azanaw ( $\sim$ kefyalewamogne@gmail.com )

Debretabore healthe science college https://orcid.org/0000-0002-9760-4841

Abebaw Addis Gelagay

University of Gondar

Ayenew Molla Lakew

University of Gondar

\section{Research}

Keywords: housemaid psychological violence, prevalence, Debre Tabor, Ethiopia

Posted Date: August 5th, 2020

DOI: https://doi.org/10.21203/rs.3.rs-52769/v1

License: (c) (i) This work is licensed under a Creative Commons Attribution 4.0 International License.

Read Full License 


\section{Abstract}

Background: psychological violence often called emotional violence is a form of violence that may result in psychological trauma. Psychological violence can destroy intimate relationships, friendships and even our relationship with us. The majority of human beings may have been a victim of some form of psychological violence at some point of their life. Therefore this study expected to assess the magnitude of Psychological violence and its associated factors among housemaids.

Methods: A community based cross-sectional study was conducted from April 1-30/ 2018. About 688 study participants were selected using cluster sampling. Data were entered into Epi info version 7.2.2.6 and analyzed with SPSS version 20 then, mainly analyzed using descriptive statistic and Binary logistic regression.

Result: A community based cross-sectional study was conducted from April 1-30/ 2018 among 688 randomly selected housemaids. From 688 participated in the study, about 387(56.3\%) (95\%Cl: 52.6 $60.2)$ housemaids had experienced at least one form of psychological violence in their life time. From those who had experienced violence, $175(25.4 \%)(95 \% \mathrm{Cl}: 22.1 \%-28.6 \%)$ had experienced in the last 12 months. No formal education ( $\mathrm{AOR}=3.13,95 \% \mathrm{Cl}: 1.76,5.57)$, primary education (AOR=2.09, $95 \% \mathrm{Cl}: 1.12$, $3.90)$, being rural (AOR=2.04,95\% Cl: $1.13,3.71)$, and family live situation and alcohol consumption of employers had significant association with housemaid psychological violence.

Conclusion: $\mathrm{n}$ this study,high prevalence of housemaid psychological violence has been reported. To resolve the problem, it is important to expand information education communication and behavioral change to empower housemaid.

\section{Introduction}

Psychological violence which includes behavior that is anticipated to intimidate and Persecute, and takes the form of threats of abandonment or abuse, confinement to the home, surveillance, threats to take away custody of the children, destruction of objects, isolation, verbal aggression and constant humiliation[1]

Violence against women has reached epidemic proportions in many societies and suggests that no racial, ethnic, or socio-economic group is protected [2]. Violence against women is a public health problem as well as a basic violation of women's human rights [3]. The impact of violence is beyond physical injuries it also accounts disability, depression, physical and reproductive problem, and risky sexual behavior [4]. Gender based violence is insidious human right issues of public consequence [5].

In the world (24-38\%) of children experienced with psychological violence[6]. in sub- Saharan Africa the experience of women with psychological sexual violence by their intimate partner ranges from $12.1 \%$ Rwanda-48.6\% Uganda[5]. In Ethiopia 24\% of women were exposed to psychological violence [7].

Generally: in the countries where the status of women were low younger women more likely to suffer from domestic violence. Ethiopia has one of the highest prevalence of both physical and sexual violence by 
their intimate partner[8]. Most study conducted on violence against women agreed that lower educational status, abuse of (alcohol, kchat, and smoke) and younger women are more likely increase experience of violence against women [9-11].

Gender based violence affected the significant segment of populations on girls and women across all group and classes [12]. At worldwide with in its informal nature of domestic worker still challenge to regulation and policy implementation lead to limited opportunities of access to social and legal protection[13]

Universally all type of violence overlap in relationship and a significant public health problem worldwide but the level and pattern of violence greatly varies between setting, culture and segment of the population [14]

However there are many study conducted on violence in the globe and also in our country Ethiopia there is lack of information about magnitude and associated factors of violence against housemaids.

Therefore this study will assess the magnitude of violence against housemaids and also try to identify factors associated with housemaid violence. So this research finding hope to alleviate scarce of information on housemaids violence in South Gondar zone.

\section{Materials And Methods}

\section{Study design and period}

Community based cross- sectional study design was conducted from April, 1-30/ 2018. The study was conducted in Debre Tabor town Northwest Ethiopia. Debre Tabor is the capital town of South Gondar zone which is located $666 \mathrm{~km}$ far from Addis Ababa the capital city of Ethiopia; to northwest Ethiopia. As the data obtained from South Gondar zone city administration the town had 92,530 populations (2010 EPY).

\section{Sample size and sampling procedure}

The sample size was determined using single population proportion formula, taking $62.3 \%$ prevalence of psychological violence against married women in a study conducted in Debre-tabor town north west Ethiopia[15],by considering $95 \% \mathrm{Cl}, 5 \%$ margin of error, 1.5 design effect and $20 \%$ non-respondent rate. Finally 688 study participants were included in the study.

Cluster sampling was employed to select study participants. In this study area there are four Kebeles; from those kebeles $50 \%$ of ketenas was selected by using simple random sampling and the sample size was proportionally allocated for each Kebeles. Then, study participants in the households were selected from each selected Ketena until achieving the required number of respondents. 


\section{Data collection procedures}

A structured, pre-tested Interviewer administered questionnaire was used, that was adopted from WHO multi country study and then was translated in to the local language Amharic. Four MPH for supervisors and 8 health extension workers for data collectors were recruited and training was provided for 3 days. The questionnaire was pretested on $5 \%$ of the total sample size from wereta town. Data was collected through face to face interviewing from each respondent. Psychological violence was taken as the dependent variable while employers' characteristics and housemaids' characteristics were considered as independent variables. Housemaid psychological violence was measured as if a housemaid experience any acts of insulted her or made her feel bad about herself, belittled or humiliated her in front of other people, done things to scare or intimidate her on purpose ,he looked at her, by yelling and smashing things, threatened when asking her friends/family, threatened to hurt her or someone she care about was considered as "yes" otherwise "no"[16].

\section{Data quality control}

Data was collected by well-trained data collectors using pretested questionnaires. Training was given to supervisors and data collectors. Data were reviewed and checked for its completeness before entering for analysis.

\section{Data processing and analysis:}

Data were entered into Epi- info version 7.2.2.6 and exported into SPSS version 20.0. the data were also cleaned, coded, and analyzed with SPSS. Descriptive analysis was done to describe the different characteristics of the employers and housemaids. Binary logistic regression analysis was done to identify association between independent and dependent variables. To identify factors significantly associated with the outcome variable adjusted odds ratio (AOR) with $95 \%$ confidence interval (Cl) was used. Variable having $p$-value less than 0.05 were considered as significant predictors.

\section{Results}

\section{Socio-demographic characteristics of respondents}

About 688 were participated in the study, among the participants $419(60.9 \%)$ were in the age group of 1519 years, with the mean age of 19.72 years $( \pm 4.55 \mathrm{SD})$. About $348(50.6 \%)$ of participants had no formal education. Participants, 564(82\%) were previously resided in rural area. About $642(93.3 \%)$ of were orthodox Christian. Around 619(90\%) of were single. Regarding housemaid's family situation, about 278(40.4\%) them had both father and mother. Participants, 317(46.1\%) were paid from 301-500 ETB. Concerning work experience $491(71.4 \%)$ of housemaid had 1-4 years of work experience. About $448(65.1 \%)$ of were start work at the age of 15 years and above.(table 1 ) 
Table 1 Socio-demographic characteristics of housemaid, Debre Tabor town, 2018( $n=688)$. 


\begin{tabular}{|c|c|c|}
\hline Characteristics & Number & Percent (\%) \\
\hline \multicolumn{3}{|l|}{ Age in year } \\
\hline $15-19$ & 419 & 60.9 \\
\hline $20-24$ & 177 & 25.7 \\
\hline$\geq 25$ & 92 & 13.4 \\
\hline \multicolumn{3}{|l|}{ Educational status } \\
\hline No formal education & 348 & 50.6 \\
\hline Primary education & 189 & 27.5 \\
\hline Secondary education and above & 151 & 21.9 \\
\hline \multicolumn{3}{|l|}{ Previous resident } \\
\hline Urban & 124 & 18 \\
\hline Rural & 564 & 82 \\
\hline \multicolumn{3}{|l|}{ Marital status } \\
\hline Married & 36 & 5.2 \\
\hline Single & 619 & 90 \\
\hline Divorced & 18 & 2.6 \\
\hline Widowed & 15 & 2.2 \\
\hline \multicolumn{3}{|l|}{ Religion } \\
\hline Orthodox & 642 & 93.3 \\
\hline Protestant & 8 & 1.2 \\
\hline Muslim & 38 & 5.5 \\
\hline \multicolumn{3}{|l|}{ Amount of income per month } \\
\hline $100-300$ & 311 & 45.2 \\
\hline $301-500$ & 317 & 46.1 \\
\hline$\geq 501$ & 60 & 8.7 \\
\hline \multicolumn{3}{|l|}{ Work experience } \\
\hline $1-4$ & 491 & 71.4 \\
\hline $5-9$ & 142 & 20.6 \\
\hline$\geq 10$ & 55 & 8 \\
\hline
\end{tabular}


Age of being housemaid(Mean

\begin{tabular}{|c|c|c|}
\hline $5-9$ & 13 & 1.9 \\
\hline $10-14$ & 227 & 33 \\
\hline$\geq 15$ & 448 & 65.1 \\
\hline \multicolumn{3}{|l|}{ Family live situation } \\
\hline Both father and mother alive & 278 & 40.4 \\
\hline Only father alive & 120 & 17.4 \\
\hline Only mother alive & 136 & 19.8 \\
\hline Both father and mother dead & 154 & 22.4 \\
\hline \multicolumn{3}{|l|}{ Family marital status $(\mathrm{n}=278)$} \\
\hline Live together & 194 & 69.8 \\
\hline Divorced & 84 & 30.2 \\
\hline
\end{tabular}

Table 2: Socio-demographic characteristics of employers, Debre Tabor town, 2018 


\begin{tabular}{|c|c|c|}
\hline Characteristics & Number & Percent (\%) \\
\hline \multicolumn{3}{|l|}{ Age of female employer } \\
\hline $25-29$ & 115 & 18.4 \\
\hline $30-34$ & 161 & 25.7 \\
\hline 35-39 & 110 & 17.6 \\
\hline $40-44$ & 132 & 21,1 \\
\hline $45-49$ & 32 & 5.1 \\
\hline$\geq 50$ & 76 & 12.1 \\
\hline \multicolumn{3}{|l|}{ Age of male employer $(n=636)$} \\
\hline $25-29$ & 14 & 2.2 \\
\hline $30-34$ & 87 & 13.7 \\
\hline $35-39$ & 120 & 18.9 \\
\hline $40-44$ & 161 & 25.3 \\
\hline $45-49$ & 64 & 10.1 \\
\hline$\geq 50$ & 190 & 29.9 \\
\hline \multicolumn{3}{|l|}{ Female employer religion $(n=626)$} \\
\hline Orthodox & 541 & 86.4 \\
\hline Protestant & 21 & 3.4 \\
\hline Muslim & 64 & 10.2 \\
\hline \multicolumn{3}{|l|}{ Male employer religion $(n=636)$} \\
\hline Orthodox & 552 & 86.8 \\
\hline Protestant & 23 & 3.6 \\
\hline Muslim & 61 & 9.6 \\
\hline \multicolumn{3}{|c|}{ Female employer educational status $(n=626)$} \\
\hline Not read and write & 52 & 8.3 \\
\hline Read and write but no formal education & 54 & 8.6 \\
\hline Grade 1-8 & 62 & 9.9 \\
\hline Grade $9-12$ & 137 & 21.9 \\
\hline Certificate and above & 321 & 51.3 \\
\hline
\end{tabular}




\begin{tabular}{|c|c|c|c|}
\hline \multicolumn{4}{|l|}{ Male employer educational status ( $n=636)$} \\
\hline Not read and write & 4 & & 0.6 \\
\hline Read and write but no formal education & 40 & & 6.3 \\
\hline Grade 1-8 & 42 & & 6.6 \\
\hline Grade $9-12$ & 83 & & 13.1 \\
\hline Certificate and above & 467 & & 73.4 \\
\hline \multicolumn{4}{|l|}{ Marital status of employers $(n=688)$} \\
\hline Married & 549 & & 79.8 \\
\hline Single & 46 & & 6.7 \\
\hline Divorced & 57 & & 8.3 \\
\hline Widowed & 36 & & 5.2 \\
\hline \multicolumn{4}{|l|}{ Number of children employer have $(n=688)$} \\
\hline $0-3$ & 496 & & 72.1 \\
\hline 4-6 & 184 & & 26.7 \\
\hline$\geq 7$ & 8 & & 1.2 \\
\hline \multicolumn{4}{|l|}{ Employer family size } \\
\hline $1-3$ & 201 & & 29.2 \\
\hline $4=6$ & 429 & & 62.4 \\
\hline$\geq 7$ & 58 & & 8.4 \\
\hline \multicolumn{4}{|c|}{ Extended family living with employer $(n=688)$} \\
\hline Yes & 147 & & 21.4 \\
\hline No & 541 & & 78.6 \\
\hline \multicolumn{4}{|c|}{ Another housemaid living with employers $(n=688)$} \\
\hline Yes & 28 & & 4.1 \\
\hline No & 660 & & 95.9 \\
\hline \multicolumn{4}{|l|}{ Female employer occupation } \\
\hline Housewife & & 150 & 24 \\
\hline Student & & 7 & 1.1 \\
\hline Government employer & & 294 & 47 \\
\hline
\end{tabular}




\begin{tabular}{|lcc|}
\hline Private employer & 66 & 10.5 \\
\hline Merchant & 98 & 15.7 \\
\hline Pensioned & 11 & 1.8 \\
\hline Male employer occupation $(\mathbf{n}=636)$ & & \\
\hline Government employer & 387 & 60.7 \\
\hline Private employer & 98 & 15.4 \\
\hline Merchant & 122 & 19.2 \\
\hline Pensioned & 29 & 4.6 \\
\hline
\end{tabular}

\section{Socio-demographic characteristics of employers}

The mean ages of female and male employers were 33.2 years and 40.1 years respectively. Majority, $541(86.4 \%)$, of female employer and 552(86.8\%) of male employer were orthodox Christians. About $321(51.3 \%)$ of female employers and $467(73.4 \%)$ of male employers had certificate and above. Majority, $549(79.8 \%)$, of employers were married. About $496(72.1 \%)$ of employers had 0-3number of children and $429(62.4 \%)$ of employers had 4-6 family size. About $541(78.6 \%)$ of employers had no extended family and only $28(4.1 \%)$ of employers had another housemaid. About $294(47 \%)$ of female employers and $386(60.7 \%)$ of male employers were government employee. (Table2)

\section{Behavior of employers}

About $30(4.4 \%)$ of employer had smoking cigarette and $74(10.8 \%)$ of employers had chewing khat and 92(14.7\%) of female employers and $158(24.8 \%)$ of male employers had consumed alcohol. (Table 3 )

Table 3: Behavior of employer, Debre Tabor town, $2018(n=688)$ 


\begin{tabular}{|c|c|c|}
\hline Characteristics & Number & Percent (\%) \\
\hline \multicolumn{3}{|c|}{ Employer smoking status(688) } \\
\hline Yes & 30 & 4.4 \\
\hline No & 658 & 95.6 \\
\hline \multicolumn{3}{|c|}{ Frequency of employer smoking $(n=30)$} \\
\hline Sometimes & 24 & 80 \\
\hline Daily & 6 & 20 \\
\hline \multicolumn{3}{|c|}{ Employer khat chewing status(688) } \\
\hline Yes & 74 & 10.8 \\
\hline No & 614 & 89.2 \\
\hline \multicolumn{3}{|c|}{ Frequency of chewing khat(n=74) } \\
\hline Sometimes & 45 & 60.8 \\
\hline Daily & 29 & 39.2 \\
\hline \multicolumn{3}{|c|}{ Female employer alcohol consumption status $(n=626)$} \\
\hline Yes & 92 & 14.7 \\
\hline No & 534 & 85.3 \\
\hline \multicolumn{3}{|c|}{ Female employer intoxication status(n=92) } \\
\hline Yes & 4 & 4.3 \\
\hline No & 88 & 95.7 \\
\hline \multicolumn{3}{|c|}{ Frequency of female intoxication $(n=4)$} \\
\hline Sometimes & 3 & 75 \\
\hline Daily & 1 & 25 \\
\hline \multicolumn{3}{|c|}{ Male employer alcohol consumption status( $n=636)$} \\
\hline Yes & 158 & 24.8 \\
\hline No & 478 & 75.2 \\
\hline \multicolumn{3}{|c|}{ Male employer intoxication status $(n=158)$} \\
\hline Yes & 118 & 74.7 \\
\hline No & 40 & 25.3 \\
\hline Frequency of ma & & \\
\hline
\end{tabular}




\begin{tabular}{|l} 
Sometimes \\
Daily \\
ence Psychological violence
\end{tabular}

\section{Prevalence Psychological violence}

About $387(56.3 \%)(95 \% \mathrm{Cl}: 52.6 \%-60.2 \%)$ of housemaids have been experienced at least one type of psychological violence in their life time and $175(25.4 \%)(95 \% \mathrm{Cl}: 22.1 \%-28.6 \%)$ experienced in the past 12 months.

Perpetrators of psychological violence

\section{Housemaids who had been experienced with psychological violence were traumatized by around three fourth of 306(73.7\%) female employers. (fig1)}

\section{Factors associated with housemaid violence}

In binary logistic regression analysis educational status, previous resident, family residence, family live situation, employer alcohol consumption, and extended family living with employers were significantly associated with psychological violence. In the final model, educational status, previous resident, family residence, family live situation, family resident and employer alcohol consumption were remaining significantly associated with lifetime psychological violence at $5 \%$ level of significance.

The result of the study revealed that housemaids who had no formal education were 3 times (AOR=3.13, $95 \% \mathrm{Cl}: 1.76,5.57)$ and maids who had primary education were 2 times (AOR=2.09, 95\% Cl: 1.12, 3.90) more likely to experienced violence as compared to those who had secondary education and above.

Pertaining to resident of housemaids, who previously resided at rural areas were 2 times (AOR=2.04, 95\% $\mathrm{Cl}: 1.13,3.71)$ more likely to experience psychological violence than those who resided at urban.

Housemaid whose family resided rural areas were 2 times (AOR=1.84, 95\% Cl: 1.12, 3.01) more likely to experienced psychological violence than those whose families resided in urban.

Housemaid who had only father alive 2 times ( $\mathrm{AOR}=2.34,95 \% \mathrm{Cl}: 1.32,4.14)$ and only mother alive 2 times (AOR=2.08, 95\% Cl: $1.22,3.55)$, more likely to experienced psychological violence as compared to those who had both father and mother alive.

With regard to alcohol consumption, housemaid whose female employer drank alcohol were 8 times $(\mathrm{AOR}=7.98,95 \% \mathrm{Cl}: 3.49,18.29)$ and male employer drank alcohol were 3 times ( $\mathrm{AOR}=2.59,95 \% \mathrm{Cl}: 1.49$, 
4.49) more likely to experience psychological violence as compared to those who not drank alcohol (Table 4).

\section{Table 4: Factors associated with lifetime experience of housemaid Psychological violence, Debre Tabor town, 2018.}




\begin{tabular}{|llll}
\hline Variables & $\begin{array}{l}\text { housemaid } \\
\text { violence }\end{array}$ & COR $(95 \% \mathrm{Cl})$ & AOR $(95 \% \mathrm{Cl})$ \\
& YES $(\%)$ & NO $(\%)$ &
\end{tabular}

\section{Previous residence}

\begin{tabular}{lllll} 
Urban & $40(5.8)$ & $84(12.2)$ & 1 & 1 \\
\hline Rural & $347(50.4)$ & $217(31.5)$ & $3.36(2.22,5.086 .24)$ & $\mathbf{2 . 0 4 ( 1 . 1 3 , 3 . 7 1 ) *}$
\end{tabular}

\section{Educational status}

\begin{tabular}{|c|c|c|c|c|}
\hline $\begin{array}{l}\text { No formal } \\
\text { education }\end{array}$ & 218(31.7) & $130(18.9)$ & $2.54(1.72,3.76)$ & $3.13(1.76,5.57)^{* \lambda}$ \\
\hline Primary education & $111(16.1)$ & $78(11.3)$ & $2.28(1.47,3.53)$ & $2.09(1.12,3.90)$ * \\
\hline $\begin{array}{l}\text { Secondary } \\
\text { education and } \\
\text { above }\end{array}$ & $58(8.4)$ & $93(13.5)$ & 1 & 1 \\
\hline
\end{tabular}

\section{Family live situation}

\begin{tabular}{lllll}
$\begin{array}{l}\text { Both father and } \\
\text { mother alive }\end{array}$ & $102(14.8)$ & $169(24.6)$ & 1 & 1 \\
\hline Only father alive & $77(11.2)$ & $43(6.3)$ & $3.09(1.98,4.83)$ & $\mathbf{2 . 3 4}(1.32,4.14)^{*}$ \\
\hline Only mother alive & $87(11.2)$ & $49(7.1)$ & $3.06(2.00,4.69)$ & $\mathbf{2 . 0 8 ( 1 . 2 2 , 3 . 5 5 ) *}$ \\
$\begin{array}{l}\text { Both father and } \\
\text { mother not alive }\end{array}$ & $1154(22.4)$ & $33(4.8)$ & $6.33(4.01,9.98)$ & $.97(.06,16.37)$
\end{tabular}

\section{Family residence}

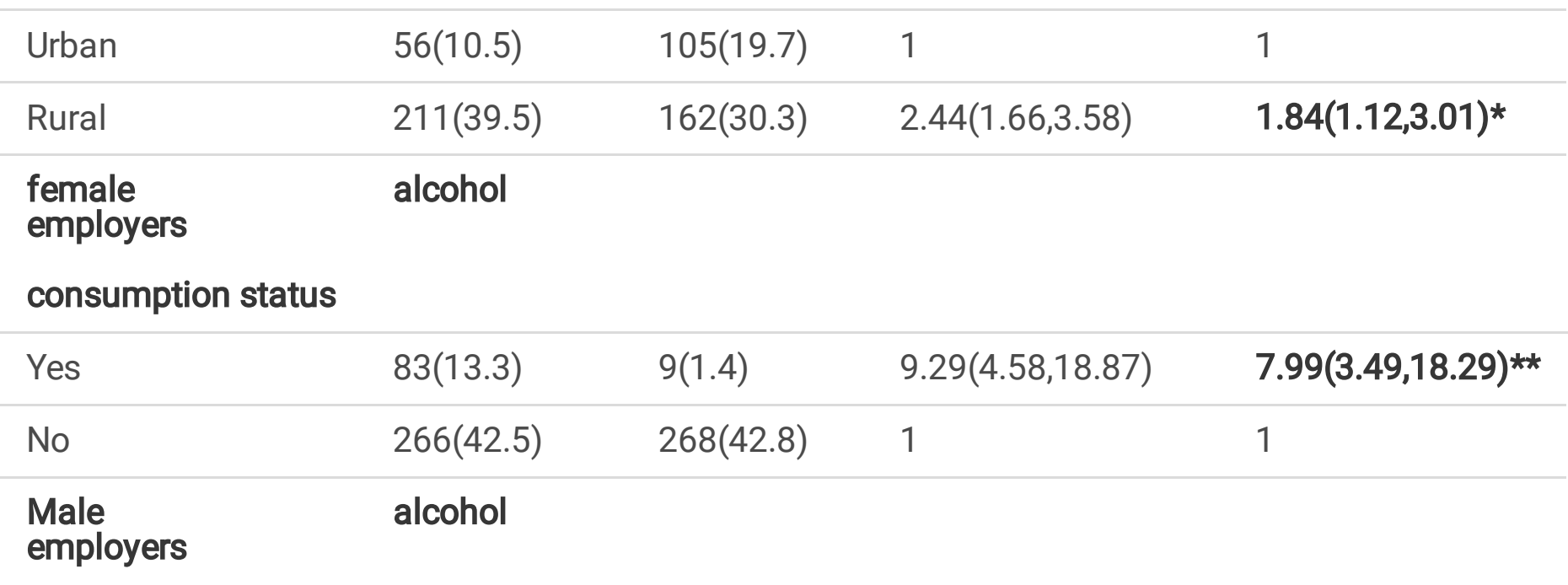

\section{consumption status}

$\begin{array}{lllll}\text { Yes } & 126(19.8) & 32(5) & 4.18(2.72,8.06 .401) & \text { 2.59(1.49,4.49)** } \\ \text { No } & 252(39.6) & 226(35.5) & 1 & 1\end{array}$




\section{Extended \\ family/relative \\ living}

with employer

\begin{tabular}{|c|c|c|c|c|}
\hline Yes & 106(15.4) & $41(6)$ & $2.39(1.61,3.58)$ & $1.63(.92,2.90)$ \\
\hline No & $281(40.8)$ & $260(37.8)$ & 1 & 1 \\
\hline
\end{tabular}

Keys: $1=$ reference $\quad *=$ significant with $p<0.005, * *=$ significant with $p<0.001$

\section{Discussion}

This study tried to find the prevalence and factors associated with housemaid Psychological violence in Debre Tabor town. The prevalence of at least one form of Psychological violence during their life time was $(56.3 \%)(95 \% \mathrm{Cl}=52.6,60.2)$. This study finding was in line with a study conducted at rural Vietnam (55.4\%)[17] and eastern India (52\%)[18]. This finding was higher as compared to a study conducted Ghana, eastern Sudan, Tanzania, and Romania (30\%, 30.1\%, 39\%, and 45.1\%) respectively [19-22]. This could partly be due to socio-demographic difference, former studies included government employee. Women who had better employment status could have access of information about violence and they can easily protect themselves.

Educational status of respondents was significantly associated with housemaid psychological violence. Where, housemaids who have no formal education were 3 times more likely to experience violence. Comparable finding was obtained from a study conducted in western Ethiopia ,northwest Ethiopia, Eastern Sudan, rural Vietnam and WHO multicounty study showed that women who had low educational status were more likely experience domestic violence $[9,10,17,18,20,23,24]$. This is due to the fact that low educational status of women had no power to protect the violence.

Rural residence of respondents and their families were significantly associated with experience of housemaid violence. Housemaid who resided in rural areas and whose family resided in rural area were 2 times more likely to experienced violence as compared to who resided urban area. This finding was consistent with a study conducted in western Ethiopia, eastern India, around Gondar, and Gondar town northwest Ethiopia, showed that rural residency were more likely experience domestic violence $[9,18,23$, 25]. Housemaids who previously resided at country side had no information about violence and they couldn't complain to legal bodies. But this finding contradicted with a study from Ghana, showed that women who resided urban areas were $35 \%$ more likely increase risk of domestic violence[19] this could be due to socio- demographic and socio-cultural difference of the study participants.

Housemaid who had only father alive were 2 times more likely experience lifetime psychological violence, respondents who had only mother alive were 2 times more likely 
experience housemaid psychological violence when compared to those who had both father and mother alive respondents. This finding in line with other study[11]. Family support could increase the confidence of housemaid this help to protect them from any violence.

Alcohol consumption of employers was significantly associated with housemaid violence. Participants whose female employers drank alcohol were 8 times and male employer drank alcohol were 3 times more likely experience life time housemaid psychological violence when compared to participants whose employer not take alcohol. This finding consistent with a study conducted in Mekele town, northern Ethiopia and Debre Tabor town northwest Ethiopia showed that employers and husbands drink alcohol were more likely increase experience of violence than those whose employers and husbands not drink alcohol respectively[11, 15, 26]. This is due to the fact that alcohol has depressive mental impairment and which encourages human beings to undertake violence against their house maids.

\section{Conclusion}

In this study, high prevalence of psychological violence has been reported. Being rural resident, no formal education, only father alive, only mother alive and alcohol consumption of employers were important predictors of housemaid violence. Women and children affair office need to expand of information education communication and behavioral change on housemaid to empower and report violence as a crime and also need to improve community awareness about housemaid violence.

Finally, further research need to address the economical violence of housemaid is very important.

\section{Limitation Of The Study}

The limitation of this study was that the data collectors interviewed only housemaid as a proxy respondents for their employer that depend on housemaid report only, this lead to bias when they come to reporting employer characteristics. And had been encountered with social desirability bias due to sensitivity of the information and also exposed with recall bias due to the nature of cross-sectional design.

\section{Abbreviations}

AOR: Adjusted Odds Ratio, Cl: Confidence Interval, COR: Crude Odds Ratio,

ETB: Ethiopian Birr, OR: Odds Ratio, SD: Standard Deviation, SPSS: Statistical Package for Social Sciences, WHO: World Health Organization.

\section{Declaration}

\section{Ethical approval and consent to participate:}


Ethical approval was obtained from university of Gondar, institute of public health ethical review committee. Official letter was obtained from Debre Tabor town administration, mayor office. From each participant, who aged 18 years and above written informed consent was obtained. Participants who less than 18 years age written assent was obtained from their employers after clear describing purpose, benefit, and risk of the study and their right on decision of participation in the study.

\section{Consent to publish}

Not applicable

\section{Availability of Data and Materials}

The datasets analyzed during this study are available from the authors on reasonable request.

\section{Competing interest}

The authors declare that they have no competing interest.

\section{Funding}

There was no external funding source for this study.

\section{Authors' contributions}

KAA designed the study, developed the proposal, participated in the data collection, performed analysis and interpretation of data and drafted the paper. AAG and AML assisted in the design of the study, proposal writing, data analysis, and interpretation of the study. KAA carried out the manuscript preparation. All authors reviewed and approved the final manuscript.

\section{Acknowledgements}

We are highly grateful to thank the study participants, data collectors and supervisors

\section{Reference}

1. Khan M, Kapoor S, Cooraswamy R. Domestic violence against women and Innocenti Digest. 2000;6:1-30. 
2. Alhabib S, Nur U, Jones R. Domestic violence against women: Systematic review of prevalence studies. Journal of family violence. 2010;25(4):369-82.

3. Organization WH. Global and regional estimates of violence against women: prevalence and health effects of intimate partner violence and non-partner sexual violence: World Health Organization;

4. Jacob K. Global status report on violence prevention 2014.

5. Borwankar R, Diallo R, Sommerfelt AE. Gender-based violence in sub-Saharan Africa: a review of Demographic and Health Survey findings and their use in national planning.

6. Krug EG, Mercy JA, Dahlberg LL, Zwi AB. The world report on violence and health. The lancet. 2002;360(9339):1083-8.

7. ICF CSACEa. Ethiopia Demographic and Health Survey 2016. DHS 2017:294-5.

8. Berhane Y. Ending Domestic violence against women in Ethiopia. The Ethiopian Journal of Health Development (EJHD). 2017;18(3).

9. Abeya SG, Afework MF, Yalew AW. Intimate partner violence against women in western Ethiopia: prevalence, patterns, and associated factors. BMC public health. 2011;11(1):913.

10. Girmatsion F, Mulusew G. Intimate partner physical violence among women in Shimelba refugee camp, northern Ethiopia. BMC public health. 2012;12(1):125.

11. Milete Zenebe AG, Huruy Assefa. Magnitude and factors associated to physical violence among house maids of Mekelle town, Tigray, northern, Ethiopia: A cross sectional study. science publishing group. 2014(2328-5745).

12. Group IGW. Addressing gender-based violence through USAID'S health programs: a guide for health sector program officers. Addressing gender-based violence through USAID'S health programs: a guide for health sector program officers: IGWG;

13. Blackett A. Exploited, Undervalued-and Essential: Domestic Workers and the Realisation of their Rights. Edited by Darcy du Toit. Pretoria: Pretoria University Law Press, 2013. 380 pp. ZAR225. 00, \$22 paperback, available online. Wiley Online Library;

14. Heise L, Fulu E. What works to prevent violence against women and girls? State of the field of violence against women and girls: what do we know and what are the knowledge gaps. Pretoria, South Africa: Medical Research Council.

15. AA Muche AAaAA. Magnitude and correlates of gender-based violence among married women in Northwest Ethiopia. Afr J Med Med Sci. 2017;46:213-25.

16. Organization WH. WHO multi-country study on women's health and domestic violence against women: summary report of initial results on prevalence, health outcomes and women's responses.

17. Vung ND, Ostergren P-O, Krantz G. Intimate partner violence against women in rural Vietnam-different socio-demographic factors are associated with different forms of violence: Need for new intervention guidelines? BMC Public Health. 2008;8(1):55.

18. Babu BV, Kar SK. Domestic violence against women in eastern India: a population-based study on prevalence and related issues. BMC public health. 2009;9(1):129. 
19. Adjah ESO, Agbemafle I. Determinants of domestic violence against women in Ghana. BMC public health. 2016;16(1):368.

20. Ali AA, Yassin K, Omer R. Domestic violence against women in Eastern BMC public health. 2014;14(1):1136.

21. Kapiga S, Harvey S, Muhammad AK, Stöckl H, Mshana G, Hashim R, et al. Prevalence of intimate partner violence and abuse and associated factors among women enrolled into a cluster randomised trial in northwestern Tanzania. BMC public health. 2017;17(1):190.

22. Rada C. Violence against women by male partners and against children within the family: prevalence, associated factors, and intergenerational transmission in Romania, a cross-sectional study. BMC Public health. 2014;14(1):129.

23. Yigzaw T, Yibric A, Kebede Y. Domestic violence around Gondar in northwest Ethiopia. Ethiopian Journal of Health Development. 2004;18(3):133-9.

24. Abramsky T, Watts $\mathrm{CH}$, Garcia-Moreno $\mathrm{C}$, Devries $\mathrm{K}$, Kiss L, Ellsberg M, et al. What factors are associated with recent intimate partner violence? Findings from the WHO multi-country study on women's health and domestic violence. BMC public 2011;11(1):109.

25. Bifftu BB, Dachew BA, Tadesse Tiruneh B, Zewoldie AZ. Domestic Violence among Pregnant Mothers in Northwest Ethiopia: Prevalence and Associated Advances in Public Health. 2017;2017.

26. Muche AA, Adekunle AO, Arowojolu AO. Gender-Based Violence among Married Women in Debre Tabor Town, Northwest Ethiopia: A Qualitative Study.

\section{Figures}

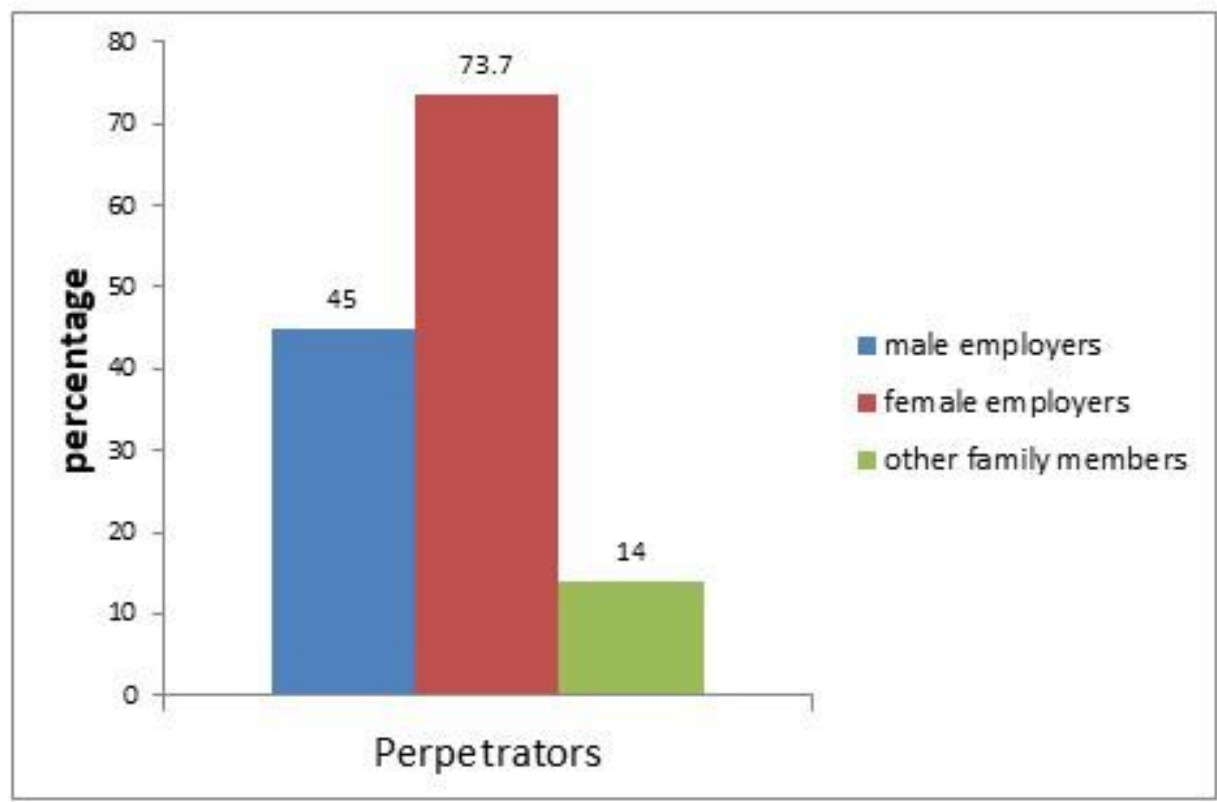

\section{Figure 1}


Housemaid psychological violence with their perpetrators at Debre Tabore town. 